This is a post-print version of Sert, S., Garrone, P., Melacini, M., \& Perego, A. (2018).

Corporate food donations: altruism, strategy or cost saving?. British Food Journal. , Vol. 120 No. 7, pp. 1628-1642. https://doi.org/10.1108/BFJ-08-2017-0435

\title{
Corporate food donations: altruism, strategy or cost saving?
}

Sedef Sert*^, Paola Garrone^, Marco Melacini^, Alessandro Perego ${ }^{\wedge}$, Politecnico di Milano

\section{Purpose}

This paper is aimed at enhancing the understanding of motives behind corporate giving and at finding out whether and when operational efficiency plays a major role in the case of surplus food donations by food supply chain companies.

\section{Design/methodology/approach}

A multiple case study methodology has been applied considering a sample of 16 food sector companies operating in Italy. Three cases have been analysed in depth to highlight the contextual factors that make cost savings possible and donations sizeable and regular.

\section{Findings}

The results show that the willingness of companies to reduce operational costs plays a relevant role in managerial decisions concerning the recovery and donation of unsold food, although to different degrees across the supply chain stages.

\section{Originality/value}

The paper shows that not only strategic and moral motives, but also economic efficiency concern plays an important role in the managerial decision making process pertaining to surplus food donations.

Keywords: Corporate philanthropy; Cost saving; Efficiency; In-kind donations; Operations; Surplus Food; Waste

*Corresponding author: Sedef Sert (sedef.sert@polimi.it); ^Address: Department of Management Economics and Industrial Engineering, Politecnico di Milano, Via Lambruschini 4B, 20156, Milan, Italy 


\section{Introduction}

Environmental issues and societal problems do not spur innovation by themselves; indeed, some companies are more prone to undertake innovations towards a greater sustainability. In today's competitive environment, sustainable waste management appears to be an important leverage for companies, and donating surplus products and resources is an increasingly relevant practice for sustainable waste management. Innovation in the operational systems is necessary in order to modify the existing processes to introduce a new player in the "extended supply chain", i.e. non-profit organizations.

The literature classifies the motives behind corporate donations in two streams, as strategic motives (responding to external pressures imposed by the government and the general public in the form of lawsuits and media attention) and altruistic motives (reacting to the degree of need experienced by recipients of charitable help) (Gan, 2006). However, this classification doesn't take into account if the donations are cash or in-kind. On the other hand, corporate gifts are increasingly including products or non-financial resources, instead of money, with significant implications on the production and logistics processes. Therefore, the impact of operational efficiency as a main motive behind corporate in-kind donations remains as an unanswered question. In order to contribute to this untapped area of research, we investigate the relationship between philanthropic decision making and cost saving concerns by studying the case of surplus food donations by food supply chain companies.

The choice of food sector as the empirical setting was further motivated by the increasing attention that is being paid to the paradox of food insecurity in a world of food waste i.e. more than 800 million people worldwide were estimated to be suffering from regularly not getting enough food, while approximately 1.3 billion tonnes is wasted globally per year (FAO, 2015; Gustavsson et al. 2011). Although some studies have mentioned the economic value created by surplus food donations such as saving of disposal fees (Campbell et al., 1999) or obtaining of tax deductions and tax credits (Deloitte, 2014), no research has so far been focused on operational efficiency as a key driver.

Besides the food waste paradox, another concept has recently become popular, i.e. the Circular Economy, defined as "keeping resources within the economy when a product has reached the end of its life, so that they can be productively used again and again and hence create further value" (European Commission, 2014). The reuse and redistribution of products are generally central concepts in the Circular Economy paradigm and "need to be applied to the planning and decision-making process of waste management practices" (Young and Tilley, 2006, p. 404). However, the current academic and policy debates neglect the social potential of reuse and redistribution options (Murray et al., 2015). Understanding whether and how corporate in-kind donations are cost efficient can be considered a building block of the intellectual effort necessary to reconcile the circular model of economies with the social dimension of sustainable development. The analysis of the surplus food case can be considered a contribution to this endeavour.

The remainder of this paper is organized as follows. The next section provides the background, the literature review and the research questions. The data collection and data analysis methods 
are then introduced. The main results of the cross-case content analysis and a description of the in-depth cases are then presented in the subsequent section. Finally, the main conclusions are discussed and a potential route for future study is proposed.

\section{Literature review}

The idea of "charitable contributions" by companies lies at the centre of several academic debates. In 1968, Schwartz defined corporate philanthropic contributions as "a one-way flow of resources from a donor to a donee, a flow voluntarily generated by the donor though based upon no expectation that a return flow, or economic quid pro quo, will reward the act" (Shwartz, 1968, p. 480). However, one should recognize that corporate giving is an instance of the socially responsible behaviour of business enterprises, and as such is not synonym with lack of returns, and may still be an expression of self-interest. Corporate donations may be a means to obtain a charter to exist from society and augment business viability (“....if business wishes to retain its present social role and social power, it must respond to society's needs and give society what it wants"; Davis, 1973, p.314). In other words, corporate giving can be described as a "pragmatic legitimacy" instrument (Suchman, 1995, p. 578). According to this view, business enterprises would donate to show their congruence with the values and beliefs of closer social groups, and getting benefits from the latter.

After the pioneering studies, many authors have described corporate donations as a form of "strategic" philantropy. Saiia et al. (2003, p. 170) defined strategic philanthropy as "the practice of giving corporate resources to address non-business community issues that also benefit the firm's strategic position and, ultimately, its bottom line". According to Porter and Kramer (2002), corporate philanthropy offers companies a set of competitive tools that can be used to attain the maximization of value creation. Contributions are motivated by profit considerations (Fry et al., 1982), also because the companies that make higher philanthropic contributions have better reputations (Brammer and Millington, 2005). As Chen et al. (2008, p. 141) stated, "Charitable contributions appear to be used by corporations as a tool of legitimization".

On the other hand, a different stream of research arose from a "moral" perspective on corporate philanthropy. A few studies have demonstrated that human elements may interact and play an important role in a firm's decision to become involved in philanthropic activities (Shaw and Post, 1993). Intrinsic motivations refer to those motivations that arise from inside of an individual, rather than from the possibility of obtaining any external or outside rewards, such as money or grades. In other words, individuals attain satisfaction, well-being and even fun from giving donations, even though there is no further award for them (Brief and Motowidlo, 1986). Campbell (1999) demonstrated that firms are likely to indicate altruistic motivations as the main reason for giving; on the other hand, firms that do not give to charities tend to use business reasons to explain their lack of involvement.

Some studies have claimed that only strategic motives drive corporate philanthropy. Moir and Taffler (2004) found that legitimacy and positive branding are the main reasons for corporate giving, and only one eut of the 60 organizations that were analyzed exhibited a potential for pure altruism. After conducting a survey of Australian firms, Marx (1999) found that community, public and employee relations were rated less frequently than expanding existing 
markets, developing new markets, and increasing sales as the main motive. Later, Noble et al. (2008) confirmed that Australian corporations donate for strategic profit maximization or political reasons; altruistic and managerial utility motives were not found to be factors of particular importance.

Finally, some researchers have obtained evidence on both drivers. After conducting interviews in Salvador, Sanchez (2000) found that Salvadorian companies were motivated by both altruistic and politically strategic factors for their corporate philanthropy actions. Gan (2006) conducted a quantitative survey on Fortune 500 companies from 1997 to 2003. Corporate giving was found to be both a strategic response to external pressures coming from the government and the public as lawsuits and media attention, and an altruistic response to the charitable aid recipients'needs. In other words, moral and strategic motives of corporate philanthropy may intertwine. Corporate concerns for "the right thing to do" could still reflect a socially constructed value system ("moral legitimacy", Suchman, 1995, p. 579), and as such coexist with more pragmatic strategic orientations.

Considering that corporate giving can take the form of either cash or in-kind resources, such as personnel time, or outputs such as goods or services, one should ask:

\section{Are strategic and moral motives always sufficient to explain the corporate giving decision?}

In fact, donating inputs and outputs is practiced in various sectors, ranging from electronics to textile, and several examples can be extracted from corporate social responsibility communications. One of the most obvious examples can be found in the food sector. Particular attention has recently been paid to surplus food, due to the alarming existence of food insecurity, even in developed countries (Gentilini, 2013). Regular donations by companies to non-profit organizations have been used as a surplus food management method (Booth and Whelan, 2014; Lindberg et al., 2014; Santini and Cavicchi, 2014). Surplus production occurs when the company produces more than the quantity demanded, and when the goods are not marketable for certain reasons but are still suitable for consumption (Aleksandar and Smaje, 2008; Schneider, 2013). Although the main aim of the companies is to prevent surplus, its generation is inevitable in some cases, and once it has been generated it has to be managed (Garrone et al., 2014b; Sert et al., 2016). Depending on the reason for the generation of surplus food, companies can adopt different approaches, such as remanufacturing, repackaging, discounts, promotions, sales on secondary markets, distribution to employees or donation to non-profit organizations (Garrone et al., 2016).

Surplus products have to undergo several operations, such as storage and transportation, when they are redistributed (Garrone et al., 2014a). Consequently, the operational efficiency of surplus food management i.e. the motives related to cost and cost savings is another dimension that has to be considered. Therefore whether strategic and moral motives as suggested by the literature are sufficient to explain the decision should be questioned. As a result, the first research question has been finalized as follows:

RQ1a: Are strategic and moral motives sufficient to explain the decision of surplus food donations?

$R Q 1 b$ : Do operational efficiency motives have an impact on surplus food donation decisions? 
"Supply uncertainty" is one of the main characteristics of the "supply" that impacts the food redistribution system (Sengul-Orgut et.al., 2016). Understanding the contextual factors that make surplus food donations regular would give practical lessons to non-profit organizations to build a strong relationship with donor companies. Therefore, once the impact of operational efficiency on surplus food donation decisions has been understood, the contextual factors where those motives are relevant should be identified. As a result, the following second research question has been formulated:

RQ2: What are the contextual factors that spur cost savings and in this way make surplus food donations regular?

\section{Methodology}

Considering the nature of the research questions and the disagreement in the literature about the motives behind corporate philanthropic practices, a qualitative research methodology was adopted in two steps:

- Cross-case analysis for RQ1a and RQ1b

- In-depth case studies for RQ2

The case study method was selected for various reasons. First of all, the research questions address the motives behind surplus food donations, i.e. a "why" issue, and the conditions that make donations more feasible. i.e. a "how" issue. Even though the focus is on a contemporary phenomenon, the situation in which the donation decisions are made are not under control of the researchers. All these circumstances make case study the most appropriate methodology for the problem addressed, according to Yin (2013). Second, multiple case study analysis provides a good basis for further research because it ensures a better external validity than a single case study (Eisenhardt, 1989). Therefore, a multiple case study analysis was performed.

A summary of the adopted methodology is given in Figure 1.

Figure 1 - Summary of the cross-case content analysis

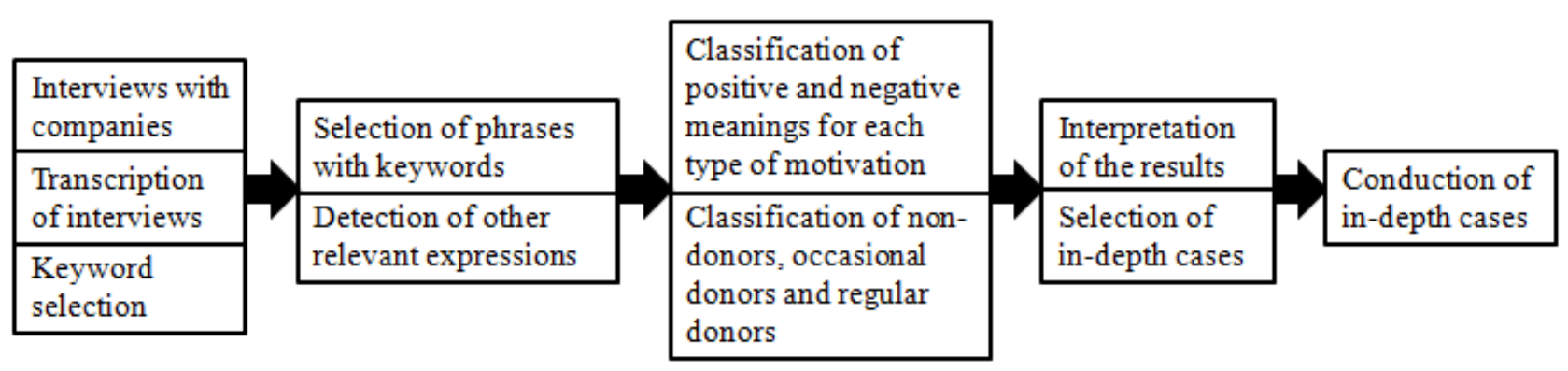

In order to ensure reliability of the results by standardizing the investigation (Yin, 2013), a case study protocol was designed. A semi-structured interview questionnaire was prepared 
considering an extensive literature review on the motives behind corporate philanthropy and surplus food management.

The questionnaire covered 5 key areas:

1. Contact details and characteristics of the firm: The first section was designed to collect general information about the interviewed company.

\section{Quantitative and qualitative assessment of the generated surplus food: Information related} to the amount of surplus food generated in the companies and about the monitoring and measurement of the surplus food was collected.

3. Surplus food management: In the third section, the reasons for the surplus food generation and options adopted to manage the surplus food were discussed.

4: Surplus food donation: The fourth section was designed to obtain knowledge on the donation process; the structure of the internal processes and relationships with third parties were discussed.

5. Motivations, drivers and barriers: This section discussed the level of commitment to donation activities as well as the main motivations, the internal and external constraints and the surplus food management drivers.

The database of companies was obtained from a Business Association that is active in 4 cities of the same- North Italy region. Focusing on only one region makes it possible-to reduce at least partially the potential confounding impact of external factors on the cross-case analysis, e.g. differences in the quality of infrastructures or the diffusions of food aid organizations. At the end, a total of 16 companies were interviewed from three stages of the food supply chain, that is, manufacturing, retail and food service. The farming sector was excluded since the Italian agriculture sector and its surplus food management practices are mainly driven by European Union laws and regulations, unlike the other food supply chain stages.

If the sample characteristics are considered, it is possible to notice that there are domestic, multinational as well as small, medium and large companies in the sample. Because of confidentiality reasons, the companies are only named and referred to with the letters A to P in the description of the sample (Table 1) and in the subsequent empirical analysis.

Table 1 - List of interviews

\begin{tabular}{|c|l|l|}
\hline Case & Job title & $\begin{array}{l}\text { Main characteristics of the companies and experts in the } \\
\text { industry }\end{array}$ \\
\hline A & President & $\begin{array}{l}\text { Domestic company that produces flour with annual sales of 33 } \\
\text { million euros }\end{array}$ \\
\hline B & President & $\begin{array}{l}\text { Domestic company that produces tomato sauce with annual sales } \\
\text { of } 30 \text { million euros }\end{array}$ \\
\hline C & $\begin{array}{l}\text { Head of External } \\
\text { relations }\end{array}$ & $\begin{array}{l}\text { Multinational company that produces yogurt with annual sales of } \\
1000 \text { million euros }\end{array}$ \\
\hline D & President & $\begin{array}{l}\text { Domestic company that produces beverages with annual sales of } \\
23 \text { million euros }\end{array}$ \\
\hline
\end{tabular}




\begin{tabular}{|c|l|l|}
\hline $\mathbf{E}$ & Operations manager & $\begin{array}{l}\text { Multinational company that produces baby food with annual } \\
\text { sales of } 200 \text { million euros }\end{array}$ \\
\hline $\mathbf{F}$ & $\begin{array}{l}\text { Quality control } \\
\text { manager }\end{array}$ & $\begin{array}{l}\text { Domestic company that produces frozen desserts with annual } \\
\text { sales of 120 million euros }\end{array}$ \\
\hline $\mathbf{G}$ & President & $\begin{array}{l}\text { Domestic company that produces cheese with annual sales of } \\
120 \text { million euros }\end{array}$ \\
\hline $\mathbf{H}$ & President & $\begin{array}{l}\text { Domestic company that produces bread substitutes with annual } \\
\text { sales of 5 million euros }\end{array}$ \\
\hline $\mathbf{I}$ & Plant manager & $\begin{array}{l}\text { Domestic company that produces snacks, biscuits and cakes with } \\
\text { annual sales of 5 million euros }\end{array}$ \\
\hline $\mathbf{J}$ & $\begin{array}{l}\text { Supply planning } \\
\text { manager }\end{array}$ & $\begin{array}{l}\text { Multinational company that produces cheese with annual sales of } \\
150 \text { million euros }\end{array}$ \\
\hline $\mathbf{K}$ & Operations manager & $\begin{array}{l}\text { Domestic company with 12 stores and with annual sales of 12 } \\
\text { million euros }\end{array}$ \\
\hline $\mathbf{L}$ & President & $\begin{array}{l}\text { Domestic company with 4 stores and with annual sales of 5 } \\
\text { million euros }\end{array}$ \\
\hline $\mathbf{M}$ & $\begin{array}{l}\text { Innovation and service } \\
\text { manager }\end{array}$ & $\begin{array}{l}\text { Domestic company with 53 stores and with annual sales of 1000 } \\
\text { million euros }\end{array}$ \\
\hline $\mathbf{N}$ & President & Domestic company that prepares 300 thousand meals per year \\
\hline $\mathbf{O}$ & $\begin{array}{l}\text { External relations } \\
\text { responsible }\end{array}$ & Multinational company that prepares 17 million meals per year \\
\hline $\mathbf{P}$ & Supply chain manager & Multinational company that prepares 70 million meals per year \\
\hline
\end{tabular}

1

2 Following the suggestions of Voss et al (2002), the outline of the interview protocol was sent in advance to ensure that the interviewees were sufficiently prepared. The selection of the interviewees was performed by the company itself, after the case study protocol had been sent, in order to ensure that the appropriate person interviewed.

Each interview lasted about one hour, and was conducted by two researchers. All the interviewees were conducted in Italian and recorded.

After the transcription and the translation of the interviews to English, the keywords for each type of motivation were identified, as a first analysis, as follows:

- Strategic motives: culture, mission, corporate, reputation, risk

- Moral motives: correct, proud, pity, shame, embarrassing, unfortunate

- Operational efficiency motives: preferable, expense, expenditure, cost, saving, benefit, convenient, cheaper

After identifying the relevant phrases of the interviewees related to each keyword, a second analysis was performed in order to be able to understand the significance of other phrases with reference to a specific concept. For instance, when an interviewee mentioned "disposal is an extra activity", this statement was included in the cost savings category, although it did not have any of the keywords that had been identified in the previous step. 
In the third step of the analysis, all the phrases selected were classified as either positive (+) or negative (-). For instance, if the interviewee mentioned that "You feel proud of what the Company is doing and what you are doing" the evaluation was recorded as positive $(+)$ in the moral motivation category. Similarly, if the interviewee said that "We do not donate because we have no way of knowing whether the product is well conserved or well transported, and therefore there is a risk for the brand no matter what" the evaluation was recorded as negative (-) in the strategic motivation category (Table 2).

Finally, a second classification was made by checking the pattern of surplus food donations and the stage of the supply chain, that is, manufacturing, retail or food service. As far as the pattern of donation is concerned, the companies were classified as (Table 3):

- Non-donors

- Occasional donors

- Regular donors

After the cross-case analysis, three cases - i.e. one manufacturer, one retail trade and one food service - were selected in order to obtain a better understanding of the contextual factors that induce cost savings and as a result make donations regular.

\section{Findings}

\subsection{Cross-case analysis}

The interviewees' phrases that were classified as strategic, moral or operational efficiency motives and the evaluations of the case studies that were classified as positive or negative are shown in Table 2.

Table 2 - Operational efficiency, moral and strategic motives

\begin{tabular}{|l|l|l|}
\hline Operational efficiency motives & Moral motives & Strategic motives \\
\hline $\begin{array}{l}(-) \text { "From the economic perspective, there } \\
\text { are other preferable alternatives." (Case A) }\end{array}$ & $\begin{array}{l}(+) \text { "It has } \\
\text { happened that some } \\
\text { customers } \\
\text { cancelled their } \\
\text { orders, so instead } \\
\text { of searching for } \\
\text { surplus, we can always rework." (Case B) }\end{array}$ & $\begin{array}{l}(+) \text { "There had already } \\
\text { been donations due to } \\
\text { our corporate culture } \\
\text { and mission." (Case } \\
\text { C) }\end{array}$ \\
$\begin{array}{l}(+) \text { "We pay for disposal. ." (Case C) } \\
\text { someone else to } \\
\text { buy at a lower } \\
\text { price, we preferred } \\
\text { as a result we will always opt for its } \\
\text { recovery and its reworking, even at the } \\
\text { expense of a loss of elements used for the } \\
\text { production of the final product: bottle, cap, } \\
\text { label etc." (Case D) }\end{array}$ & $\begin{array}{l}\text { Bank, and we } \\
\text { believe this is the } \\
\text { correct solution." } \\
\text { (Case B) }\end{array}$ & $\begin{array}{l}\text { Food Bank, which/and } \\
\text { this strengthens our } \\
\text { mission proposition. } \\
\text { In fact, we believe the } \\
\text { first 1000 days (from - } \\
9 \text { months to 2 years of } \\
\text { age) are very }\end{array}$ \\
\hline
\end{tabular}




\begin{tabular}{|c|c|c|}
\hline $\begin{array}{l}\text { (+) "Donation does not create a cost for the } \\
\text { company, it is a saving." (Case E) } \\
\text { (-) "Repacking is cheaper for us, as the price } \\
\text { of the product is higher than the packaging." } \\
\text { "Donation procedure documentation is an } \\
\text { expenditure" "We duplicate all the processes } \\
\text { when we use the donation channel." (Case } \\
\text { F) } \\
\text { (+) "It is a donation, so there are fiscal } \\
\text { benefits; it is cheaper than disposal." (Case } \\
\text { G) } \\
\text { (-) "The mixed product cannot be donated, } \\
\text { they are completely fresh, but we have to } \\
\text { put labels on them that show all the } \\
\text { ingredients." "It is complicated and a } \\
\text { question of organization." (Case H) } \\
\text { and without them the food cannot reach the } \\
\text { end consumer through non-profit } \\
\text { organizations." (Case O) } \\
\text { (-) "It would be easier to throw away all the } \\
\text { food that we cannot sell." (Case M) } \\
\text { (+) "For us this channel (donation) is } \\
\text { cheaper than discarding." (Case I) } \\
\text { (-) "We could not find a non-profit } \\
\text { organisation to collect our surplus due to the } \\
\text { small size of the quantities and the fact that } \\
\text { (-) "It is not conven an extra activity." (Case J) } \\
\text { organizations to collect our goods." (Case to their expiry date." } \\
\text { (-) }\end{array}$ & $\begin{array}{l}\text { (+) "We see no } \\
\text { barriers to } \\
\text { donation, what we } \\
\text { are fighting is food } \\
\text { waste." (Case C) } \\
\text { (+) "You feel } \\
\text { proud of what the } \\
\text { company is doing } \\
\text { and what you are } \\
\text { doing." (Case E) } \\
\text { (+) } \\
\text { "Unfortunately, } \\
\text { there are many } \\
\text { families in trouble } \\
\text { throughout the } \\
\text { year." (Case G) } \\
\text { (+) "Throwing } \\
\text { away instead of } \\
\text { donating is a pity." } \\
(\text { Case J) } \\
\text { food that could be } \\
\text { (+) "Why are we } \\
\text { doing this? This is } \\
\text { because waste is an } \\
\text { insult to the current } \\
\text { economic } \\
\text { situation." (Case } \\
\text { M) } \\
\text { (+) "Since we have } \\
\text { the surplus food, } \\
\text { we are looking for } \\
\text { ways to manage it; } \\
\text { otherwise the } \\
\text { alternative would } \\
\text { be throwing it } \\
\text { away, which is a } \\
\text { pity." P) }\end{array}$ & $\begin{array}{l}\text { important for the/a } \\
\text { baby to grow healthy. } \\
\text { However, many } \\
\text { families in Italy do not } \\
\text { have the possibility of } \\
\text { buying this necessary } \\
\text { food for their babies". } \\
\text { (Case E) } \\
\text { (+) "I do not know the } \\
\text { motivation, which is a } \\
\text { decision made by the } \\
\text { general management." } \\
\text { "We have a very strict } \\
\text { internal procedure that } \\
\text { has matured after } \\
\text { many years of not } \\
\text { giving." (Case J) } \\
\text { (+) "Food waste is a } \\
\text { corporate theme, so } \\
\text { we manage it." (Case } \\
\text { F) }\end{array}$ \\
\hline
\end{tabular}




\begin{tabular}{|l|l|l|}
\hline $\begin{array}{l}(-) \text { "If we go by van to where we produce } \\
100 \text { meals and generate } 2 \text { surplus food } \\
\text { meals, it would cost more to pick up those 2 } \\
\text { meals than to buy and that makes no sense." } \\
\text { (Case P) }\end{array}$ & $\begin{array}{l}\text { used by other } \\
\text { people is a shame." } \\
\text { (Case N) }\end{array}$ & $\begin{array}{l}\text { matter what." (Case } \\
\text { O) }\end{array}$ \\
$\begin{array}{l}(-) \text { "Here, there is no organization to collect } \\
\text { the food and the transport organisation } \\
\text { is/would be an expense." (Case N) }\end{array}$ & & $\begin{array}{l}(+) \text { This is our } \\
\text { corporate culture." } \\
\text { (Case P) }\end{array}$ \\
\hline
\end{tabular}

2 Table 3 summarizes the results of each case and for each motivation as positive (+) or negative $3(-)$, and distinguishes between the non-donors, occasional donors and regular donors. Each 4 class is examined hereafter.

Table 3 - Evaluation of operational efficiency, moral and strategic motives

\begin{tabular}{|c|c|c|c|c|c|}
\hline Case & Supply chain stage & $\begin{array}{c}\text { Operational } \\
\text { Efficiency }\end{array}$ & Moral & Strategic & Donation \\
\hline A & Manufacturing & - & & & None \\
\hline D & Manufacturing & - & & & None \\
\hline H & Manufacturing & - & & & None \\
\hline K & Retail trade & - & & - & None \\
\hline L & Retail trade & - & & & None \\
\hline O & Food service & - & & - & None \\
\hline B & Manufacturing & - & + & & Occasional \\
\hline F & Manufacturing & - & & + & Occasional \\
\hline N & Food service & - & + & & Occasional \\
\hline C & Manufacturing & + & + & + & Regular \\
\hline E & Manufacturing & + & + & + & Regular \\
\hline G & Manufacturing & + & + & & Regular \\
\hline I & Manufacturing & + & & & Regular \\
\hline J & Manufacturing & + & + & + & Regular \\
\hline M & Retail trade & - & + & + & Regular \\
\hline P & Food service & - & + & + & Regular \\
\hline
\end{tabular}

$\underline{\text { Non-donors }}$

8 In this class, the companies do not have a relationship with any food aid organization or any 9 individual beneficiaries, and consequently do not donate any surplus food (Cases A, D, H, K, 10 L and O). They mentioned extra costs (six cases out of six) and negative strategic effects (two 11 cases out of six) (in particular the risk of the misuse of the food and the possibility of reputational damage to their brand) as the main reasons for their decision. 
- Manufacturers (Cases A, D and H): In Cases A, D and H, evidence from the interviews shows that the companies felt they would obtain economic disadvantages from donating. In all three companies, the production processes allow them to adopt remanufacturing. Therefore, each time surplus food is generated, it can be remanufactured in their production system and fed back to the sales system.

- Retailers (Cases $K$ and $L$ ): Like the manufacturers who do not donate any goods, the retailers who do not donate mentioned the additional cost of donation for their operations. As mentioned by both companies, the collection of surplus food by non-profit organizations is not easy. In case $\mathrm{K}$, the operations managers also mentioned the negative strategic consequences that can arise from donations, since their products are made with fresh cream.

- Food service operators (Case O): In case O, both negative strategic and economic reasons explained the choice of "no donation". They believe that they cannot control the conservation and transportation once they donate their products, and even though they would no longer be responsible for any negative consequence, the risk for their brand remains. Moreover, in order to be able to donate, they would need to buy specific additional equipment e.g. a heat sealer and containers.

\section{$\underline{\text { Occasional donors }}$}

Occasional donors are those companies that are in contact with one or more food aid organizations and donate surplus food from time to time (Cases B, F and N). In this case, the company contacts the non-profit organization only when it finds out that there is surplus food, an event that happens sporadically. All the companies perceive the presence of cost of donation compared to other surplus food management alternatives; however, they are motivated by moral or strategic considerations.

- Manufacturers (Cases B and F): All the manufacturers in the occasional donors' class mentioned the perceived cost effects of donation. Although, they do not insert donations into their operational system, due to the perceived extra cost, they are morally or strategically motivated, and if there is an opportunity to donate, they prefer to, because they believe it is the "correct" solution.

- Retailers (no example): The donation of surplus food is not common practice in the retail store management process, due to additional management costs. Only one of the three interviewed companies (Case M) donates, since they made a sustainability oriented innovation in their supply chain and changed their traditional surplus food management system through a special corporate initiative. This case is analysed in more detail in the next section.

- Food service operators (Case N): In the same way as in the case of retail stores, donation is not considered convenient for food service operators. In Case $\mathrm{N}$, the owner believes that missing out on the opportunity of being useful to people in need is a shame, and he therefore transports surplus food from time to time to some small local non-profit organizations.

\section{$\underline{\text { Regular donors }}$}

The companies that have contact with one or more food aid organizations, and donate surplus food regularly (Cases C, E, G, I, J, M and P), were classified as regular donors. In this case, 
companies and non-profit organizations have an agreement and the collection of food is made with regular time intervals defined by the surplus food generation. Regular donations are made by the companies that have positive strategic motives (five cases out of seven), moral motives (six cases out of seven) and cost savings (five cases out of seven). No cost saving motives have been observed for the retail and service sectors, while all the manufacturing companies instead mentioned cost saving as a crucial factor.

- Manufacturers (Cases $C, E, G, I$ and $J$ ): It can be seen that all the manufacturing companies that make regular donations formalize the surplus management processes in their operational system. Strategic, moral and cost saving motives are present together. Coherently with the previous literature on stakeholder pressure, strategic motives have emerged for the larger and international companies (Cases C, E and J).

- Retailers (Case M): As mentioned before, from the retail perspective, the process is highly complex, but close partnerships with food aid organizations facilitates the operations and reduces the cost of donation perceived by the retailer. This case is analysed in more detail in the next section.

- Food service operators (Case P): Company $\mathrm{P}$ is involved in a special food redistribution project, and collaborates closely with its clients and the food aid organization. This case is examined in the next section.

\subsection{In-depth cases}

Three cases were selected to understand the contextual conditions that enable companies to experience a better operational efficiency when they manage surplus food. Although surplus food donation is operationally burdensome for the retail and food service sectors, two companies, i.e. $\mathrm{M}$ and $\mathrm{P}$, were found to donate surplus products regularly to people in need. Therefore Company $\mathrm{M}$ for retail, and Company $\mathrm{P}$ for food service sector were selected for further investigation. Finally, Company E was selected among the other regular donors in the manufacturing sector, due to the special effort it had made to modify its supply chain in order to be able to direct the surplus food from the delivery points to food aid organizations instead of wasting it.

\section{Case E}

Company $\mathrm{E}$ is a manufacturer of baby food, which had an annual turnover of 200 million euros in 2014. The products are characterized by medium - long shelf lives of nine months to three years. The main customers are retailers, and distributors for baby specialists and pharmacies (directly or indirectly through wholesalers).

The company collaborates regularly with food bank in a particular project that was established to aid the proper growth of babies. The decision was taken one year ago in a corporate meeting. The main motives were explained by the manager as follows "Based on our mission, we believe the first 1000 days (till two years of age) are very important for the baby to grow healthy the health of a baby's growth. However, many families in Italy do not have the possibility of buying this necessary food for their babies. Therefore, we decided to work together with a food bank". 
There are two types of surplus food generation in the company, that is, the internal sell-by date is exceeded and the product is returned from the delivery points. If a product with a shelf life of nine months is considered, when there are five months to the expiration date, the company tries to prevent the creation of surplus food and exploit its commercial value through promotions, e-commerce and product sampling. When the shelf life is only three months, a donation channel is activated. According to the manager, this time interval was decided by the market; when a product is very close to the expiration date, is no longer acceptable on the market.

In order to be able to recover as much surplus food as possible from the delivery points, a reverse logistic network was structured. When the products become surplus in the delivery points, the company collects those products and donates them to the food bank. The possibility of donating directly from the delivery point was not considered due to the reputational risk that could be created through the misuse of the products. The company manager expressed this notion as follows: "in the end, it is our name that is at stake". He added that the entire procedure requires quality control.

This case shows that a close relationship between the company and the non-profit organization is necessary for success. "To create this collaboration, one person from outside, in this case the food bank, is necessary to explain the necessity and one person from the inside of the company to fill it", the manager added. The close collaboration reduces the transportation and administration costs but also reduces other reputational and moral concerns. Finally, the reverse logistics network created to move the surplus food from the delivery points allows the company to reduce the wasted food, even beyond the boundaries of the company's legal responsibility.

\section{$\underline{\text { Case M }}$}

Company $\mathrm{M}$ is a retail chain that operates in Italy. Its annual revenue was more than $€ 1$ billion in 2014, and it has almost 4500 employees. Ten years ago, through collaboration with a municipality and local non-profit organizations, the company set up a pilot project. This pilot project, pertaining to the redistribution of surplus food, lasted 18 months. The company then started to apply the same system in other areas, where they asked the municipalities to collaborate by identifying local non-profit organizations that dealt with poverty and food insecurity and, as a result, they activated other stores.

The recovery and donation process is structured operationally in order to be able to distribute edible food before the expiration date. Each night, the store operators check the shelves and remove the products that are close to their expiration date and the products with damaged packaging. The manager explained that if a product is very close to expiration, customers will not buy it. Therefore, they decided to remove the products from the shelves approximately two days before the expiration date instead of waiting to see whether they were bought. This decision allows flexibility in the donation activities and eventually in the downstream management of the food aid organizations. After the selection process, the products that have to be donated are stored in a specific part of the warehouse in which the storage conditions are respected, as some of the products require a temperature controlled supply chain. The following morning, the goods are picked up by the food aid organizations. 
In order to accelerate the process, the distance between the food aid organization and each store is defined as a crucial factor. Depending on the size of the store and the needs of the food aid organizations, a store can collaborate with more than one food aid organization. Each of them has a specific schedule concerning what day and time the pickup has to be carried out. A barcode system is used to identify each product and prepare the delivery note. All the donated products have to be traceable for fiscal purposes.

This case shows that by introducing only slight changes to the daily operations, retailers can reduce donation costs as a first step towards regular donations. Second, close collaboration with local non-profit organizations and municipalities can help retailers reduce the cost of transport and administration.

\section{$\underline{\text { Case P }}$}

Company $\mathrm{P}$ is a large multinational operating in the food service industry. It operates in the commercial catering field, and has 17 million meals per year. Depending on the type of client, for example company canteens, and specific contracts, Company P generally prepares the food in the client's kitchen and distributes it in the same premises.

Collaboration between Company P and the food bank was set up five years ago to ensure a high level of effectiveness and efficiency. Surplus food is generated daily in the food service, and the food has to be consumed in a very short time (usually on the same day); this requires a close collaboration between the actors i.e. company, client and the food bank. The food bank is responsible for the daily collection and transportation of surplus food.

Because of the complexity in the management of hot surplus food meals, the donation process can only take place in facilities in which certain conditions have been verified: the presence of a blast chiller, a heat sealer and special containers for the handling of the recovered food. Blast chilling is a food cooling process, and by reducing the temperature, cooked food becomes safe for storage and for later consumption. After the treatment, the products must be packaged and sealed in suitable containers and transported by appropriate means. "We can only donate where the client supports us" said the manager. If those prior conditions are not satisfied, the donation procedure cannot be applied for legal reasons. Everything is regulated in contracts drawn up between Company $\mathrm{P}$ and its clients.

The operational process involves the Company $\mathrm{P}$ employees preparing the surplus food that has to be donated after the lunch break. The food bank volunteers come every afternoon to collect the food; they control the temperature and the packaging, and sign for its removal. They then distribute the food to the needy on the same day. The food is reheated where it is consumed.

However, applying this process is not easy, and in fact not all the company's clients are involved in the project. In general, if the kitchen is small, there is no blast chiller. Moreover, according to the manager, it is necessary to produce at least 500 meals, as the non-profit organization will not pass by to pick up the food for less. "You have to assess where it is worth" said the manager, "Where we produce 100 meals and generate only two surplus food meals, going by van to pick up those two meals would cost more than buying them, and that would not make sense". 
This case shows that certain conditions are necessary in the food service field for the implementation of donation process. A non-profit organization should organize the collection by an appropriate means, and the client should support those activities.

\section{Discussion}

This study has documented that motives behind corporate food donations are a combination of strategic, moral and operational efficiency reasons. In an attempt to fill a literature gap, this research shows that cost saving willingness plays a significant role in decision making in the case of surplus food donations. Therefore, as far as the first research question, strategic and moral motives are widely discussed by the literature (Marx 1999; Sanchez, 2000; Taffler 2004; Gan, 2006; Noble 2008), but our analysis shows that they could not be sufficient to explain the corporate giving decision. When corporate donations are in-kind, the willingness to enhance operational efficiency and to save costs may also exert a significant influence toward corporate donations.

First, it was found that manufacturing companies, depending on their operational system and their type of product, can be driven to donation by cost saving concerns (Cases C, E, G, I and J). However, some companies (Cases A, B, D, F and H) have applied other convenient options to manage surplus food. In the cases in which an operational efficiency motives exists, the companies donate their surplus food regularly. In fact, they formalize surplus food management system and prioritize product donations (In-depth cases: Case E). It was also found that when companies perceive the opportunity of saving costs, they use the donation channel as a surplus food management method, even when they do not appear to be motivated strategically or morally. On the other hand, cost-related motives are not per se necessary to explain giving choice. In the present sample, two examples of regular donations were found even where the companies faced the additional costs (In-depth cases: Case M and Case P). However, what makes these cases noteworthy is the effort the companies make to decrease the cost of donation by setting up specific collaborations with non-profit organizations and introducing modifications to their daily operations. In other words, efforts are made to make corporate giving viable.

Answering the second research question, we found that the strong collaboration between companies and non-profit organizations could reduce the cost and consequently could lead to regular surplus food donations. In fact, from a managerial perspective, food redistribution is an activity that requires stakeholders to work together with companies, whether they are producers, retailers or service operators. Both non-profit organizations such as food banks, soup kitchens, food pantries work with companies and public bodies, i.e. municipalities, regional and national governments. Understanding the motives behind corporate donations and the position of donors can help non-profit organizations to collaborate more easily with the food donors and to collect a greater amount of food in a regular basis to distribute to the people in need. In-depth cases show that close relationship between the company and the non-profit organization is necessary for building an efficient surplus food redistribution system. The close collaboration reduces the transportation and administration costs, together with reputational and moral concerns. Finally, food products are highly perishable; their intrinsic recovery value is decreasing over time, thus 
requiring effective solutions for reuse and redistribution. Building an agile process to recover surplus food could also reduce the waste produced due to time lost during the distribution.

Surplus food has been considered as a typical example of corporate in-kind philanthropy. The authors believe that despite its particular features, some results may also be valid for other industries, or could stimulate research pertaining to other cases. The studied cases show that only one motive is rarely sufficient to explain the corporate donations. While moral values of employees are the most pervasive reason, they are very frequently coupled with strategic and efficiency concerns.

\section{Conclusion}

The paper shows that not only strategic and moral motives, but also economic efficiency concern plays an important role in the managerial decision making process pertaining to surplus food management. "Cost saving" is a straightforward economic incentive, whereas legitimacy concerns or ethical drivers lean on individual or firm-specific circumstances that are more difficult to foresee. In other words, efficiency is a more robust driver from the business perspective.

The research has shown that, in the current situation, food manufacturing companies can attain a cost saving by recovering and donating surplus food rather than resorting to disposal or other methods. On the other hand, the retail and food service sectors are not economically incentivized to recover and donate surplus food to the needy. Retailers and food service operators are able to donate their surplus food thanks to the intensive involvement of non-profit organizations and to the introduction of in-depth modifications to their operations i.e. inserting donation activities in the daily plans. In other circumstances, the process would be too costly to consider.

Policymakers still play important roles in those cases in which cost saving from surplus donations is not apparent. In many cases, disposal through conferral to waste management companies appears to be cheaper, but just because tariffs are artificially low (i.e. they are subsidized) or the treatment technologies are not environmentally friendly (e.g. uncontrolled landfills). In other words, companies are not taking into account the environmental cost caused by the externalities or they are not getting revenue from more environmental friendly decisionmaking. Sector and environmental regulations could restore the incentive to reduce waste through tariffs or tax exemptions for donations. There are also cases where companies are simply unaware of the potential efficiency benefit, and it would therefore be necessary for policies to compensate for the information asymmetries. In those companies in which cost savings have been found, even greater donations could be expected.

This study has some limitations and consequently left a few questions open. Firstly, the motives to donate surplus food may vary across countries, because of differences in business or contextual factors. Specific policies can provide viable incentives to food companies to donate their surplus food to charities for redistribution to those in need. Therefore understanding which public policies could provide real incentives for companies to consider donation as a preferred option deserves further investigation. 
Secondly, the authors believe that corporate in-kind donations are an increasingly important example of business conduct, in part due to the emerging debate on new paradigms, such as circular economy or sharing economy. However, very little is known about how the giving of products or the inputs could intertwine with normal business operations. Corporate philanthropy theories, which have mostly been developed and tested in the frame of cash donations, should be refined for the non-cash giving case.

Thirdly, further research is necessary to gauge the potential of industries different from the food, in terms of surplus products and resources that can be recovered and donated. In-depth qualitative analyses are necessary to understand where the recovery and donation process could be feasible and operationally efficient, and how the barriers, for instance policies regulating the food donations, that prevent firms from implementing in-kind donation practices could be eliminated.

Finally, the present study demonstrates that strategic, moral and operational motives for corporate giving are all present in business and are mutually coupled to make donations occur. However, the paper does not integrate the different theoretical perspectives behind the strategic, moral and operational views of in-kind donations or discuss the underlying assumptions. We believe that applying theories on pro-social motivations and economic incentives in business enterprises could be a promising research avenue. Indeed, whether strategic or operational "forprofit" philanthropy and altruistic attitudes of employees can co-exist, or pro-social motivations are crowded out by the explicit linkage between donations and profit (Francois and Vlassopoulos, 2008) is left to future research.

\section{References}

Alexander, C. and Smaje, C., 2008. Surplus retail food redistribution: An analysis of a third sector model. Resources, Conservation and Recycling, 52(11), pp.1290-1298.

Booth, S. and Whelan, J., 2014. Hungry for change: the food banking industry in Australia. British Food Journal, 116(9), pp.1392-1404.

Brammer, S. and Millington, A., 2005. Corporate reputation and philanthropy: An empirical analysis. Journal of Business Ethics, 61(1), pp.29-44.

Buchholtz, A.K., Amason, A.C. and Rutherford, M.A., 1999. Beyond resources: The mediating effect of top management discretion and values on corporate philanthropy. Business \& Society, $38(2)$, pp.167-187.

Campbell, L., Gulas, C.S. and Gruca, T.S., 1999. Corporate giving behavior and decision-maker social consciousness. Journal of Business Ethics, 19(4), pp.375-383.

Chen, J.C., Patten, D.M. and Roberts, R.W., 2008. Corporate charitable contributions: a corporate social performance or legitimacy strategy?. Journal of Business Ethics, 82(1), pp.131144. 
1 Davis, K., 1973. The case for and against business assumption of social responsibilities.

2 Academy of Management Journal, 16(2), pp.312-322.

3 Deloitte, 2014. Comparative Study on EU Member States' legislation and practices on food 4 donation, Final Report.

5 Eisenhardt, K.M., 1989. Building theories from case study research. Academy of Management

6 Review, 14(4), pp.532-550.

7 European Commission. Towards a circular economy: a zero waste program for Europe, (2014).

8 Brussels.

FAO, 2015. http://faostat3.fao.org/browse/D/FS/E (accessed 10 September 2016).

FASB, 1993. Statement of Financial Accounting Standards No. 116: Accounting for Contributions Received and Contributions Made. Financial Accounting Standards Board of the Financial Accounting Foundation.

Francois, P., Vlassopoulos, M., 2008. Pro-social motivation and the delivery of social services. CESifo Economic Studies, 54(1), pp. 22-54.

Fry, L.W., Keim, G.D. and Meiners, R.E., 1982. Corporate contributions: Altruistic or forprofit?. Academy of Management Journal, 25(1), pp.94-106.

Gan, A., 2006. The impact of public scrutiny on corporate philanthropy. Journal of Business Ethics, 69(3), pp.217-236.

Garrone, P., Melacini, M., Perego, A. and Sert, S., 2016. Reducing food waste in food manufacturing companies. Journal of Cleaner Production, 137, pp.1076-1085.

Garrone, P., Melacini, M. and Perego, A., 2014a. Opening the black box of food waste reduction. Food Policy, 46, pp.129-139.

Garrone, P., Melacini, M. and Perego, A., 2014b. Surplus food recovery and donation in Italy: the upstream process. British Food Journal, 116(9), pp.1460-1477.

Gentilini, U., 2013. Banking on Food: The State of food banks in high-income countries. IDS Working Papers, 2013(415), pp.1-18.

Gustavsson, J., Cederberg, C., Sonesson, U., van Otterdijk, R. and Meybeck, A., 2011. Global food losses and food waste: extent, causes and prevention. FAO, Rome.

Lindberg, R., Lawrence, M., Gold, L. and Friel, S., 2014. Food rescue-an Australian Example. British Food Journal, 116(9), pp.1478-1489.

Marx, J.D., 1999. Corporate philanthropy: What is the strategy?. Nonprofit and Voluntary Sector Quarterly, 28(2), pp.185-198.

Moir, L. and Taffler, R., 2004. Does corporate philanthropy exist?: Business giving to the arts in the UK. Journal of Business Ethics, 54(2), pp.149-161. 
Murray, A., Skene, K. and Haynes, K., 2017. The circular economy: An interdisciplinary exploration of the concept and application in a global context. Journal of Business Ethics, 140(3), pp.369-380.

Noble, G., Cantrell, J., Kyriazis, E. and Algie, J., 2008. Motivations and forms of corporate giving behaviour: insights from Australia. International Journal of Nonprofit and Voluntary Sector Marketing, 13(4), pp.315-325.

Orgut, I.S., Brock III, L.G., Davis, L.B., Ivy, J.S., Jiang, S., Morgan, S.D., Uzsoy, R., Hale, C. and Middleton, E., 2016. Achieving Equity, Effectiveness, and Efficiency in Food Bank Operations: Strategies for Feeding America with Implications for Global Hunger Relief. In Advances in Managing Humanitarian Operations, pp.229-256. Springer International Publishing.

Porter, M.E. and Kramer, M.R., 2002. The competitive advantage of corporate philanthropy. Harvard Business Review, 80(12), pp.56-68.

Saiia, D.H., Carroll, A.B. and Buchholtz, A.K., 2003. Philanthropy as strategy: When corporate charity "begins at home". Business \& Society, 42(2), pp.169-201.

Sánchez, C.M., 2000. Motives for corporate philanthropy in El Salvador: Altruism and political legitimacy. Journal of Business Ethics, 27(4), pp.363-375.

Santini, C. and Cavicchi, A., 2014. The adaptive change of the Italian Food Bank foundation: a case study. British Food Journal, 116(9), pp.1446-1459.

Schneider, F., 2013. The evolution of food donation with respect to waste prevention. Waste Management, 33(3), pp.755-763.

Schwartz, R.A., 1968. Corporate philanthropic contributions. The Journal of Finance, 23(3), pp.479-497.

Sert, S., Garrone, P., Melacini, M. and Perego, A., 2016. Surplus Food Redistribution for Social Purposes: The Case of Coop Lombardia. In Organizing Supply Chain Processes for Sustainable Innovation in the Agri-Food Industry (pp. 153-173). Emerald Group Publishing Limited.

Shaw, B. and Post, F.R., 1993. A moral basis for corporate philanthropy. Journal of Business Ethics, 12(10), pp.745-751.

Suchman, M.C., 1995. Managing legitimacy: Strategic and institutional approaches. Academy of Management Review, 20(3), pp.571-610.

Yin, R. K., 2013. Case study research: Design and methods. Sage publications.

Young, W. and Tilley, F., 2006. Can businesses move beyond efficiency? The shift toward effectiveness and equity in the corporate sustainability debate. Business Strategy and the Environment, 15(6), pp.402-415. 


\section{Appendix A.}

Table A1 - Examples of corporate in-kind donations

\begin{tabular}{|c|c|c|}
\hline \multicolumn{2}{|r|}{ Example } & Source \\
\hline Baby products & $\begin{array}{l}\text { Donated product: over } 130 \text { million diapers/nappies } \\
\text { Name of the company: HUGGIES } \\
\text { Year: 2015, Every Little Bottom programme } \\
\text { Beneficiaries: families in need }\end{array}$ & $\begin{array}{l}\text { "Huggies created the Every Little Bottom program to help provide diapers to babies in } \\
\text { need. Since the program's beginning over } 130 \text { million diapers have been donated, and } \\
\text { countless lives have been touched." https://www.huggies.com/en-us/why-huggies/every- } \\
\text { little-bottom-diaper-donations }\end{array}$ \\
\hline Food & $\begin{array}{l}\text { Donated product: } 1 \text { billion cereal and snack servings } \\
\text { Name of the company: Kellogg's } \\
\text { Year: } 2016 \\
\text { Beneficiaries: families in need }\end{array}$ & $\begin{array}{l}\text { "We have committed to providing } 1 \text { billion cereal and snack servings - more than half of } \\
\text { which are breakfasts - to children and families in need around the world by the end of } \\
\text { 2016." http://crr.kelloggcompany.com/en_US/corporate-responsibility/hunger- } \\
\text { relief/food-donations.html }\end{array}$ \\
\hline Pharmaceutics & $\begin{array}{l}\text { Donated product: } \$ 6 \text { million in medicines, vaccines and } \\
\text { direct financial contributions } \\
\text { Name of the company: MERCK } \\
\text { Year: } 2007 \\
\text { Beneficiaries: victims of the earthquake in Peru and } \\
\text { flooding in Mexico. }\end{array}$ & $\begin{array}{l}\text { "In } 2007 \text {, Merck donated nearly } \$ 6 \text { million in medicines, vaccines and direct financial } \\
\text { contributions in support of relief activities following the earthquake that struck the } \\
\text { southern coast of Peru, Tropical Storm Noel, and the severe flooding in Mexico." }\end{array}$ \\
\hline Retail & $\begin{array}{l}\text { Donated product: } 1,000 \text { tonnes of food } \\
\text { Name of the company: TESCO } \\
\text { Years: from } 2012 \text { to } 2015 \\
\text { Beneficiaries: families in need }\end{array}$ & $\begin{array}{l}\text { "In the UK, we have donated over 1,000 tonnes of surplus food from our dot.com sites } \\
\text { and fresh distribution centres to FareShare since September } 2012 \text { - enough to provide } \\
\text { over } 2.3 \text { million meals." https://www.tescotalkingshop.com/2014/10/what-were-doing- } \\
\text { to-help-cut-food-waste/ }\end{array}$ \\
\hline Shipment & $\begin{array}{l}\text { Donated product: } 263 \text { in-kind shipments across nearly } 50 \\
\text { countries } \\
\text { Name of the company: UPS } \\
\text { Year: } 2015 \\
\text { Beneficiaries: various non-profit organizations }\end{array}$ & $\begin{array}{l}\text { "Last year (2015) UPS provided } 263 \text { in-kind shipments across nearly } 50 \text { countries." } \\
\text { http://sustainability.ups.com/the-ups-foundation/ }\end{array}$ \\
\hline Electronics & $\begin{array}{l}\text { Donated product: } \$ 32 \text { Million In-Kind Software (Grant) } \\
\text { Name of the company: SIEMENS } \\
\text { Year: } 2014 \\
\text { Beneficiaries: A community college }\end{array}$ & $\begin{array}{l}\text { "Siemens Provides } \$ 32 \text { Million In-Kind Software Grant to Central Piedmont Community } \\
\text { College to Educate and Train Workers for Manufacturing Industry." }\end{array}$ \\
\hline
\end{tabular}




\begin{tabular}{|c|c|c|}
\hline Textile & $\begin{array}{l}\text { Donated product: more than } \$ 250,000 \text { worth of clothing, } \\
\text { Name of the company: GAP } \\
\text { Year: } 2012 \\
\text { Beneficiaries: victims of the disastrous storm in New } \\
\text { Jersey }\end{array}$ & $\begin{array}{l}\text { "Upon the request of the American Red Cross for much-needed clothing, Gap Inc. will } \\
\text { donate more than } \$ 250,000 \text { worth of clothing, which will be distributed tomorrow in } \\
\text { New Jersey; one of the areas hit the hardest by this week's super storm." (11/02/2012) }\end{array}$ \\
\hline White goods & $\begin{array}{l}\text { Donated product: a mobile kitchen } \\
\text { Name of the company: ELECTROLUX } \\
\text { Year: } 2009 \\
\text { Beneficiaries: victims of the earthquake in Abruzzo, in } \\
\text { Italy }\end{array}$ & $\begin{array}{l}\text { "Electrolux and its employees supported the reconstruction of Abruzzo, the Italian } \\
\text { region affected by a violent earthquake in Spring, 2009, that left } 70000 \text { homeless. } \\
\text { Electrolux Professional designed and donated a mobile kitchen, which served as } \\
\text { additional support for those living in tent cities during these difficult months." }\end{array}$ \\
\hline $\begin{array}{l}\text { Workforce time } \\
\text { (volunteering) }\end{array}$ & $\begin{array}{l}\text { Donated resource: more than } 40 \% \text { of the employees } \\
\text { Name of the company: COCA COLA } \\
\text { Year: } 2014 \\
\text { Beneficiaries: } 53 \text { Volunteer Projects }\end{array}$ & $\begin{array}{l}\text { "In } 2014 \text {, more than } 40 \% \text { of our employees participated in a total of } 53 \text { Volunteer } \\
\text { Projects, which were supported financially by Coca-Cola HBC Poland, yet developed } \\
\text { and executed within local communities by the employees themselves." http://www.coca- } \\
\text { colahellenic.com/sustainability/community/communitydevelopment }\end{array}$ \\
\hline
\end{tabular}


Table A2 - Taxonomy of corporate in-kind donations (shaded area: focus of the paper)

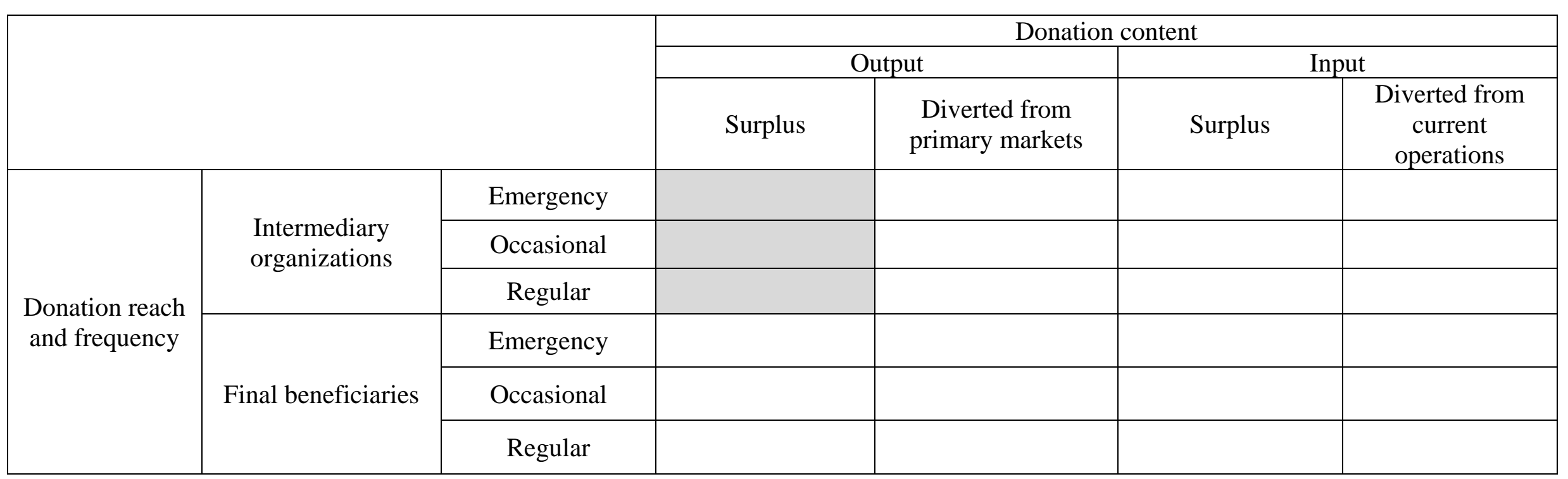

